Sains Malaysiana 49(12)(2020): 3029-3036

http://dx.doi.org/10.17576/jsm-2020-4912-14

\title{
Effect of Coating Element on Joining Stability of Sn-0.3Ag-0.7Cu Solder Joint due to Aging Test
}

(Kesan Unsur Salutan terhadap Kestabilan Sambungan Pateri Sn-0.3Ag-0.7Cu Akibat Ujian Penuaan Sesuhu)

\author{
ATIQAH MOHD AFDZALUdDIN \& MARIA ABU BAKAR*
}

\begin{abstract}
Solder joint is important for providing mechanical support and functionality of electronic packaging. Established solder joint should be able to withstand in device service operation and the environment without significant changes in terms of their microstructural evolution and mechanical properties. This study investigates the effect of the coating element ( $\mathrm{Sn}$ and $\mathrm{Ni}$ ) on the joining stability of $\mathrm{Sn}-0.3 \mathrm{Ag}-0.7 \mathrm{Cu}$ solder joint. The solder joints were exposed to different aging test for $1000 \mathrm{~h}$ to observed microstructure and micromechanical properties changes. Microstructural observation by means of intermetallic compound layer thickness due to the aging temperature effect. Joining stability by means of micromechanical changes were studied using nanoindentation approach. It was found that the elastic behavior, reduced modulus, and hardness of Sn-0.3Ag-0.7Cu solder joint has reduced due to aging test. However, the plastic behavior of Sn-0.3Ag-0.7Cu solder joint has increased with the increase of the aging temperature. It is observed that the Ni coating has a significant effect and a more stable solder joint achieved. This can be evidenced from small changes in intermetallic compound layer thickness and micromechanical properties were achieved using Ni coating as compared to Sn coating after subjected to the aging test for $1000 \mathrm{~h}$.
\end{abstract}

Keywords: Aging; coating element; micromechanical properties; nanoindentation approach; solder joint stability

\section{ABSTRAK}

Sambungan pateri adalah penting untuk memberi sokongan mekanik dan kefungsian kepada pempakejan elektronik. Sambungan pateri yang baik seharusnya boleh bertahan ketika operasi penggunaan peranti dan persekitaran tanpa perubahan yang ketara dari segi perubahan mikrostruktur dan sifat mekanik. Kajian ini mengkaji kesan salutan dengan unsur (Sn dan Ni) terhadap kestabilan sambungan pateri Sn-0.3Ag-0.7Cu. Sambungan pateri tersebut telah didedahkan pada beberapa uji kaji penuaan yang berbeza selama 1000 jam dan perubahan mikrostuktur dan sifat mikromekanik diperhatikan. Pemerhatian mikrostruktur adalah dari segi perubahan ketebalan lapisan sebatian antara logam akibat uji kaji penuaan sesuhu. Kestabilan penyambungan dari segi perubahan mikromekanik telah dikaji dengan menggunakan pendekatan pelekukan nano. Kajian telah mendapati bahawa sifat elastik, penurunan modulus dan kekerasan sambungan pateri Sn-0.3Ag-0.7Cu berkurangan akibat daripada ujian penuaan. Walau bagaimanapun, sifat plastik bagi sambungan pateri Sn-0.3Ag-0.7Cu telah meningkat seiring dengan peningkatan suhu uji kaji penuaan sesuhu. Didapati bahawa salutan Ni menunjukkan kesan ketara yang mana sambungan pateri yang lebih stabil diperoleh. Kenyataan tersebut dapat dibuktikan dengan perubahan kecil ketebalan lapisan sebatian antara logam dan sifat mikromekanik dengan penggunaan salutan Ni berbanding dengan salutan Sn selepas didedahkan pada uji kaji penuaan selama 1000 jam.

Kata kunci: Kestabilan sambungan pateri; pendekatan pelekukan nano; penuaan sesuhu; sifat mikromekanik; unsur salutan

\section{INTRODUCTION}

Solder joint possesses electrical and mechanical bearing functions between electronic components and PCB pad in the microelectronic packaging field. Electronic packaging and assembly such as surface mount technology (SMT) adopted solder and soldering process between package lead and printed circuit board (PCB). The use of $\mathrm{Sn}-\mathrm{Pb}$ solders was banned in electronic information products due to toxicity contamination and environmentally unfriendly. The RoHS directives have been issued to urge the use of lead-free solder such as $\mathrm{Sn}-\mathrm{Cu}$ (Shang et al. 2019; Yao \& Li 2020), Sn-Ag (Genanu et al. 2017; Kunwar et al. 2016) and Sn-Ag-Cu (SAC) (Fahim et al. 2018; Xiong \& Zhang 2019; Xu et al. 2017) to replace $\mathrm{Sn}-\mathrm{Pb}$. The use 
of lead-free solders is required for products subjected to harsh environments in avionics, automotive and military applications.

The formation of $\mathrm{Cu}_{6} \mathrm{Sn}_{5}$ IMC layer during the assembly process of SAC with $\mathrm{Cu}$ substrate indicated the strong metallurgical bonding between the $\mathrm{Cu}$ surface-finished printed circuit board and electronic interconnections (Guo et al. 2018; Tang et al. 2016). However, the excessive growth of the brittle $\mathrm{Cu} 6 \mathrm{Sn} 5$ phase will effect on reliability of the solder joints. Therefore, there is a need to use suitable coating materials of the $\mathrm{PCB} / \mathrm{Copper}$ substrate. The coating located on the outermost layer of PCB either organic or metallic. Surface Mount Finish (SMT) is one of the methods to provide a planar mounting surface and urge the reliability of solder joints (Kim \& Nishikawa 2017). The purpose of adding micro and nanocoating to SAC is to enhance the plastic deformation resistance of solders. This addition of reinforcing particles gives high stability of the mechanical properties of soldering whereby the solder wettability and temperature changes are negligible. Nevertheless, the researchers are attempted to use coating to form a bridge material since the coating materials act with lead free alloy to form IMCs during the soldering process. Wang et al. (2017) investigated Sn-58Bi coating on SAC305 at aging condition, the higher shear strength and through-solder ductile failure properties of IMC thickness layer. Xu et al. (2019) evaluated the Sn58Bi coating on SAC305 and were aged for $600 \mathrm{~h}$ at $80^{\circ} \mathrm{C}$. Micromechanical properties such as hardness of $\mathrm{SnBi}$ coating were reduced for pre and post aging conditions.

As it is well known, nanoindentation methods have recently become popular to determine micromechanical properties of soldering materials since the method is easy, rapid, and non-destructive technique to obtain the information of the mechanical properties especially the micro/nanoscale of materials (Ismail et al. 2020; Jalar et al. 2020). Previous solder joint nanoindentation studies of SAC were done at different temperature (Ahmed et al. 2017; Fahim et al. 2018; Hasnine et al. 2017), different coatings such as carbon-based nanomaterials graphene nanosheets (GNSs) (Khodabakhshi et al. 2017), carbon nanotubes Ag (Plevachuk et al. 2019), Ni (Huber et al. 2016), Al (Nor Ilyana 2017), nanoceramics (Yakymovych et al. 2017), and nanometals (Ani et al. 2018).

Most prior researcher is working on the solder mechanical properties and aging effects such as shear testing, tension, and compression of miniature lead free solder (Hasnine et al. 2017; Xu et al. 2019). Nevertheless, there is more limited number in literature that studied aging effects by micromechanical loading of $\mathrm{Ni}$ and Sn coating of SAC307 lead free soldering using stencil method. Our previous work suggested that the Ni coating can control the intermetallic growth exposed to the aging test (Abu Bakar et al. 2018). In this paper, the changes in micromechanical properties will be further analyzed on the effect of the coating element towards the solder joint stability. The main objective of this study was to investigate the effect of Sn and Ni coating the solder SAC 307 micromechanical properties micro solder joints at different isothermal aging temperature. Nanoindentation was used to evaluate the reduced modulus, hardness, elastic and plastic behaviors. Additionally, EDS and FESEM were used to observe the intermetallic layer compound the Sn and Ni coating SAC 307. The influence of Sn and $\mathrm{Ni}$ elements on the micromechanical properties of solder joint SAC 307 was discussed.

\section{MATERIALS AND METHOD}

A printed circuit board (PCB) with $\mathrm{Cu}$ metallization layer has been coated with (a) Sn layer and (b) Ni layer. These coated $\mathrm{PCB} / \mathrm{Cu}$ was then soldered with a lead-free solder paste of $99 \% \mathrm{Sn}-0.3 \% \mathrm{Ag}-0.7 \% \mathrm{Cu}$ (SAC 0307). Solder particle used in the solder paste is type 4 with a diameter range of approximately $\sim 30 \mathrm{~mm}$. The solder paste was printed into the coated PCB using the stencil. The printed PCB was then reflowed using a reflow oven (Madell Technology Corporation) at $235^{\circ} \mathrm{C}$. The as-reflow samples were then subjected to aging with temperature of 60 , 90,120 , and $150^{\circ} \mathrm{C}$ for $1000 \mathrm{~h}$. This is similar to high temperature storage testing which is normally been used in reliability testing of electronic packaging as suggested by JEDEC (2009). The aging activities were carried out to induce the growth of IMC, due to the diffusion process. Then, the samples were cross-section following standard metallography with consideration given for soft materials. The microstructural observation was carried out using field emission scanning electron microscope (FESEM) equipped with an energy dispersive spectrum (EDS) and optical microscope with image analysis capability. The IMC growth indicated by the increment of IMC thickness has been analyzed through considering stereometry and statistical analysis which 300 points of IMC thicknesses were taken (Bakar et al. 2018). The micromechanical properties have been studied via nanoindenter (Micro Materials Nanotest ${ }^{\mathrm{TM}}$ ) with diamond Berkovich indenter. The indentation was made onto the solder area with a constant rate of $0.5 \mathrm{mN} / \mathrm{s}$ for both loading and unloading. The load was applied to the sample surface until reached maximum load of $10 \mathrm{mN}$, followed by dwell time for 30 $\mathrm{s}$ before unloading process.

\section{RESULTS AND DISCUSSION}

Figure 1 shows the FESEM Micrograph of Sn-0.3Ag$0.7 \mathrm{Cu}$ solder joint on $\mathrm{PCB} / \mathrm{Cu}$ with $\mathrm{Sn}$ and $\mathrm{Ni}$ coating after aging at $150^{\circ} \mathrm{C}$ for $1000 \mathrm{~h}$. It is seen that the intermetallic compound (IMC) layer on $\mathrm{PCB} / \mathrm{Cu}$ with $\mathrm{Sn}$ coating is 
thicker compared to the Ni coating. This is due to Ni layer that existed on the interface between the solder and $\mathrm{Cu}$ substrate. The EDS result in Figure 2 showing the presence of $\mathrm{Sn}$ and $\mathrm{Cu}$ elements for intermetallic growth for the solder joints. The presence of thin Ni coating is confirmed in Figure 2(b).
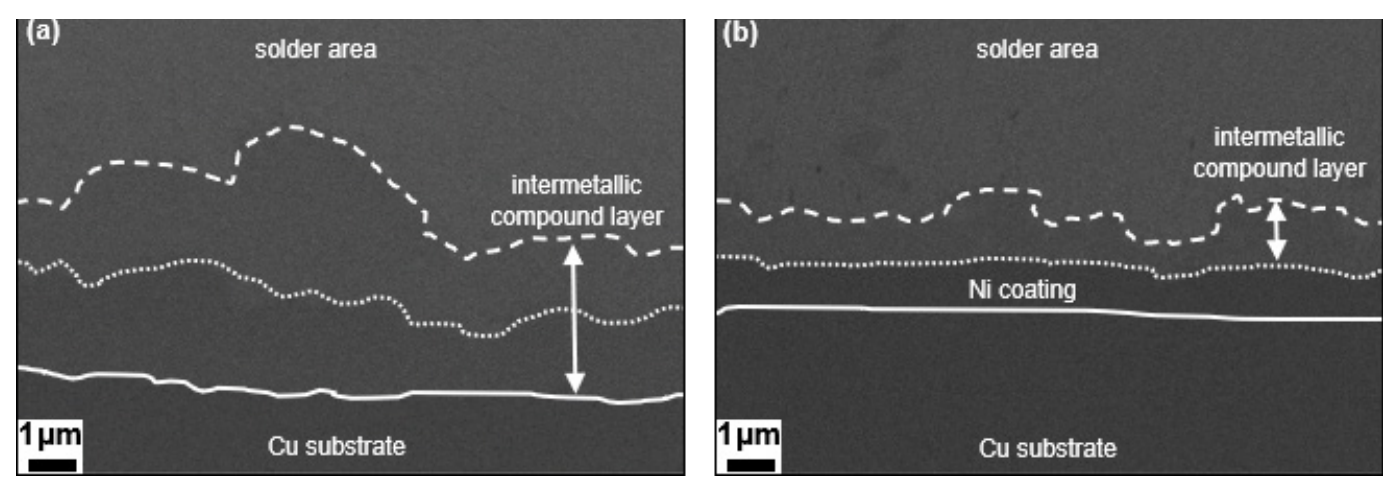

FIGURE 1. FESEM Micrograph of Sn-0.3Ag-0.7Cu solder joint on $\mathrm{PCB} / \mathrm{Cu}$ with: (a) Sn, and (b) Ni coating after aging at $150^{\circ} \mathrm{C}$ for $1000 \mathrm{~h}$
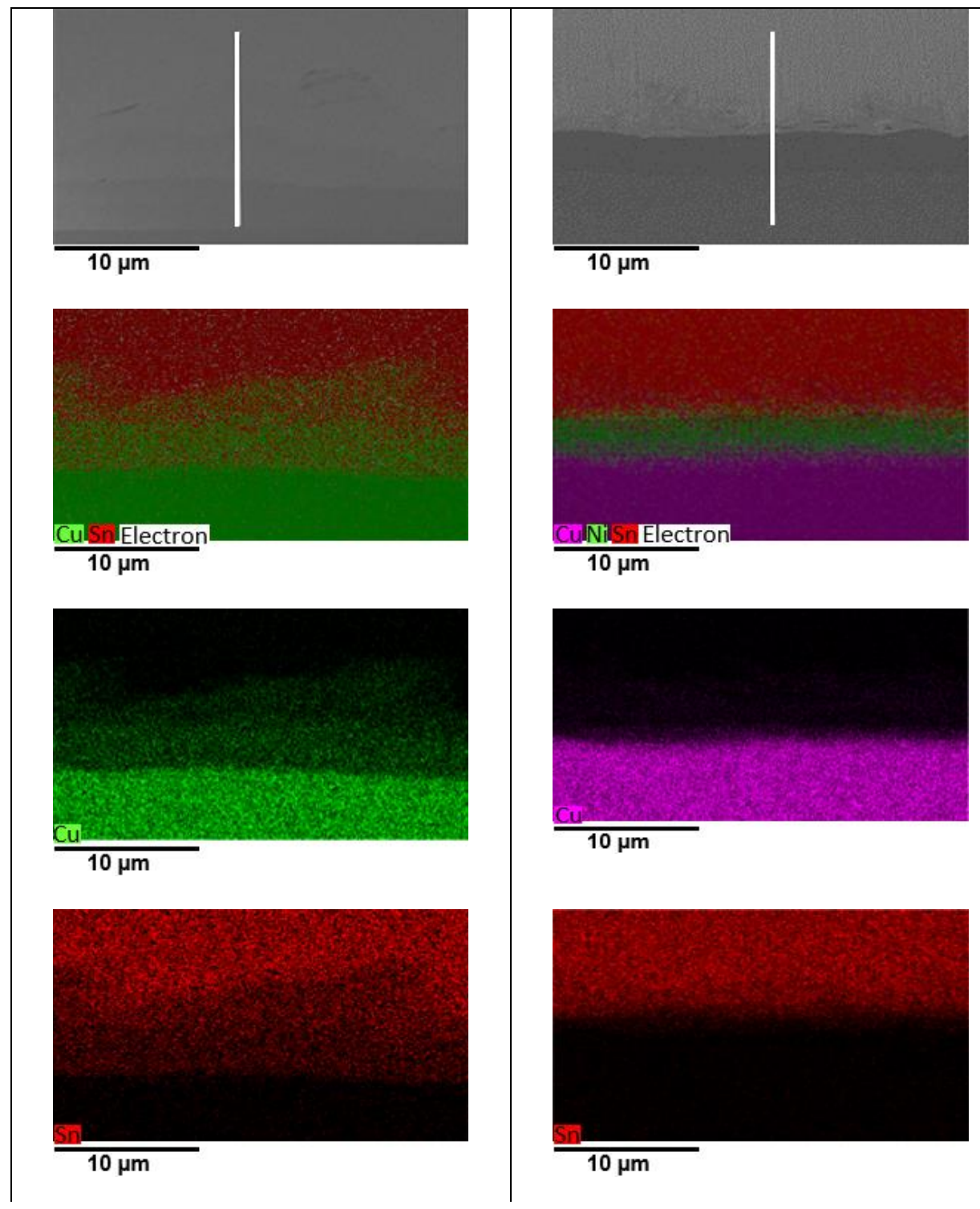

$10 \mu \mathrm{m}$

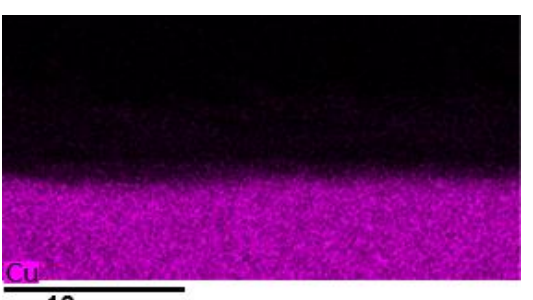

$10 \mu \mathrm{m}$

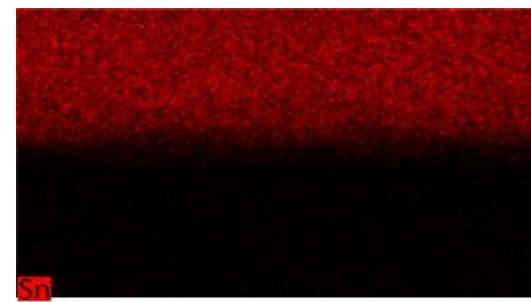

$10 \mu \mathrm{m}$ 


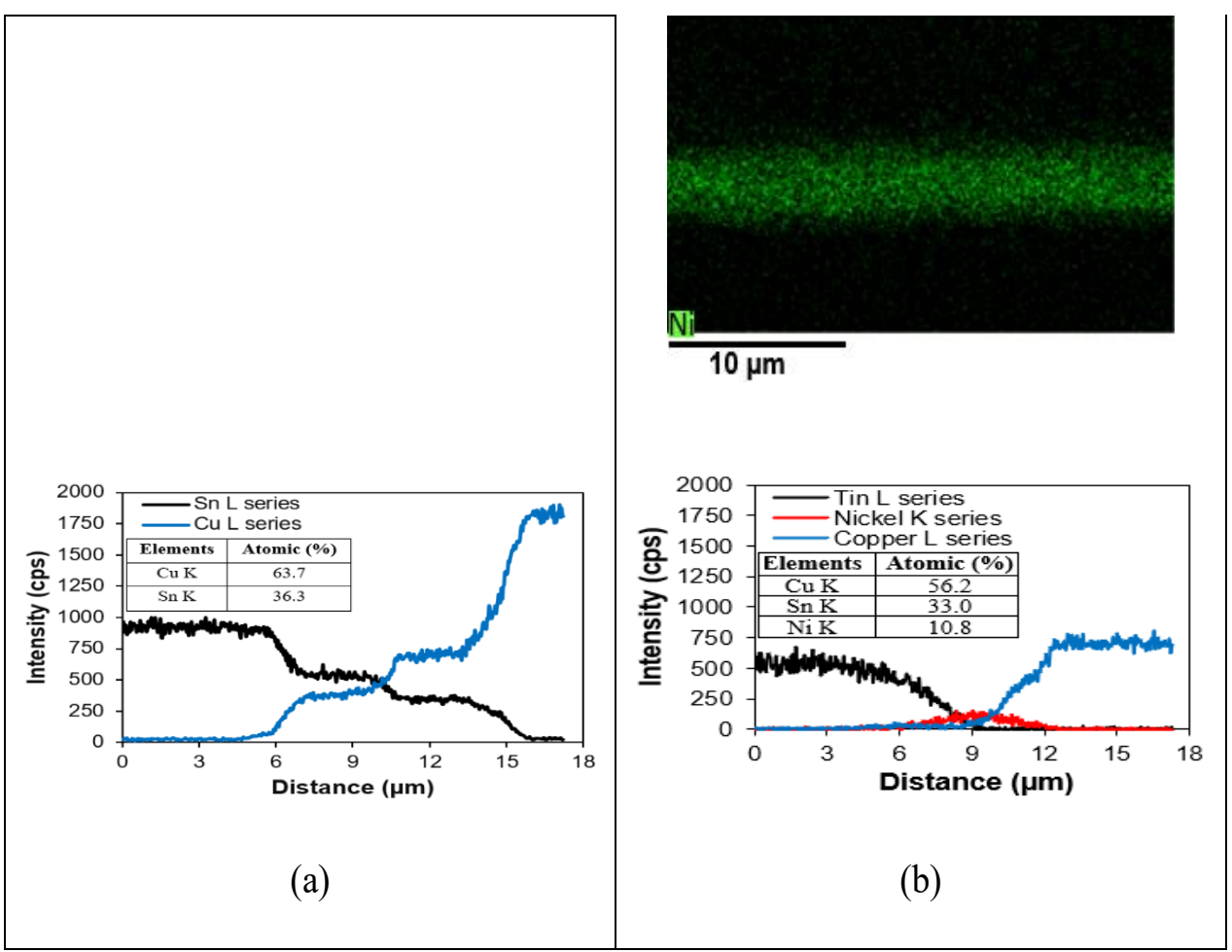

FIGURE 2. EDS analysis of interfacial intermetallic layer of Sn-0.3Ag-0.7Cu solder joint on $\mathrm{PCB} / \mathrm{Cu}$ with: (a) Sn, and (b) Ni coating subjected to aging for $1000 \mathrm{~h}$

IMC layer thickness results are shown in Figure 3. Intermetallic compound (IMC) of $\mathrm{Sn}-0.3 \mathrm{Ag}-0.7 \mathrm{Cu}$ solder joint on $\mathrm{PCB} / \mathrm{Cu}$ with $\mathrm{Ni}$ and $\mathrm{Sn}$ coatings has increased progressively with aging temperature. The thickness of IMC for the solder joint on Sn coating is $3.3 \mu \mathrm{m}$ for the controlled sample has increased up to $8.3 \mu \mathrm{m}$ after aging at $150^{\circ} \mathrm{C}$. IMC on Ni coating has shown smaller changes from $2.0 \mu \mathrm{m}$ for a controlled sample and increase to $5.7 \mu \mathrm{m}$ after aging at $150{ }^{\circ} \mathrm{C}$. The increment of IMC layer thickness is 3.7 and $5.0 \mu \mathrm{m}$ for $\mathrm{Ni}$ and $\mathrm{Sn}$ coating respectively due to aging temperature of $1000 \mathrm{~h}$. Our previous work also has reported on the activation energy for intermetallic growth (Bakar et al. 2018). Higher activation energy is obtained for $\mathrm{Ni}$ coating, $41 \mathrm{~kJ} / \mathrm{mol}$ compared to $\mathrm{Sn}$ coating, $39 \mathrm{~kJ} / \mathrm{mol}$. This result demonstrated that the coating elements have a profound effect on the IMC growth. This in agreement with observation by Anuar et al. (2020), the IMC thickness of electroless Ni coating/SAC405 after the aging time (1000 h) at range of $4.45 \mu \mathrm{m}$ which is higher form our findings. Nevertheless, the thinner IMC thickness could represent good micromechanical properties and better metallurgical bonding of soldering (Ramli et al. 2019).

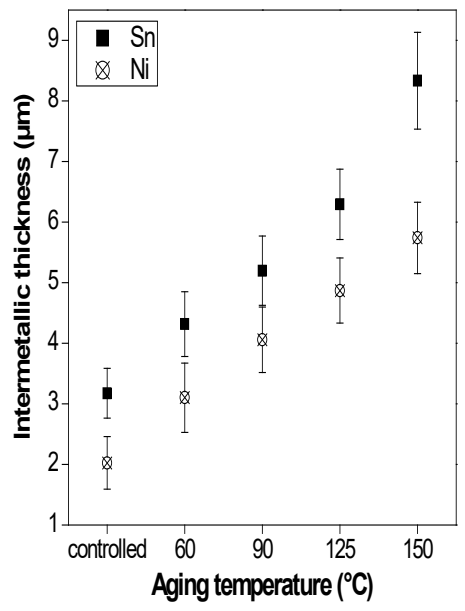

FIGURE 3. Intermetallic thickness of $\mathrm{Sn}-0.3 \mathrm{Ag}-0.7 \mathrm{Cu}$ solder joint on $\mathrm{PCB} / \mathrm{Cu}$ with different coating subjected to aging for $1000 \mathrm{~h}$ 
Figure 4 shows the load versus penetration depth curves of $\mathrm{Sn}-0.3 \mathrm{Ag}-0.7 \mathrm{Cu}$ solder joint on $\mathrm{PCB} / \mathrm{Cu}$ with different coating subjected to aging at $150{ }^{\circ} \mathrm{C}$ for 1000 $\mathrm{h}$. The load displacement curve profile presented a solder joint behavior from the elastic region to the plastic region. Penetration depth results during the loading process are shown in Figure 5. It is observed that the maximum and plastic depth were increased with the increase of the aging temperature. Maximum depth for the solder joint on Ni coating shows small changes from 1382 to $1495 \mathrm{~nm}$ after aging at $150{ }^{\circ} \mathrm{C}$ as compared to Sn coating from 1274 to $1510 \mathrm{~nm}$. The value of plastic depth is 1261 to $1498 \mathrm{~nm}$ for $\mathrm{Sn}$ coating after the aging temperature at 150 for 1000 h. While for Ni coating, the value of plastic depth is 365 $\mathrm{nm}$ to $1489 \mathrm{~nm}$ after aging temperature at 150 for $1000 \mathrm{~h}$. The increase of plastic depth changes by $19 \%$ Sn coating and $9 \% \mathrm{Ni}$ coating were found for plastic depth changes.

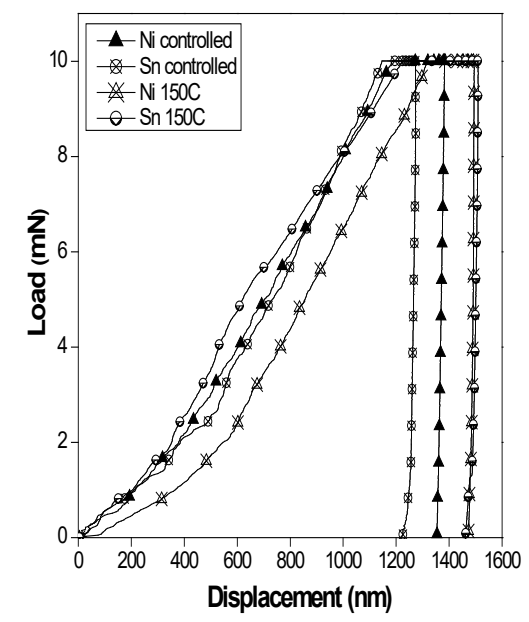

FIGURE 4. Load displacement curve of Sn-0.3Ag-0.7Cu solder joint on $\mathrm{PCB} / \mathrm{Cu}$ with different coating subjected to aging at $150^{\circ} \mathrm{C}$ for $1000 \mathrm{~h}$
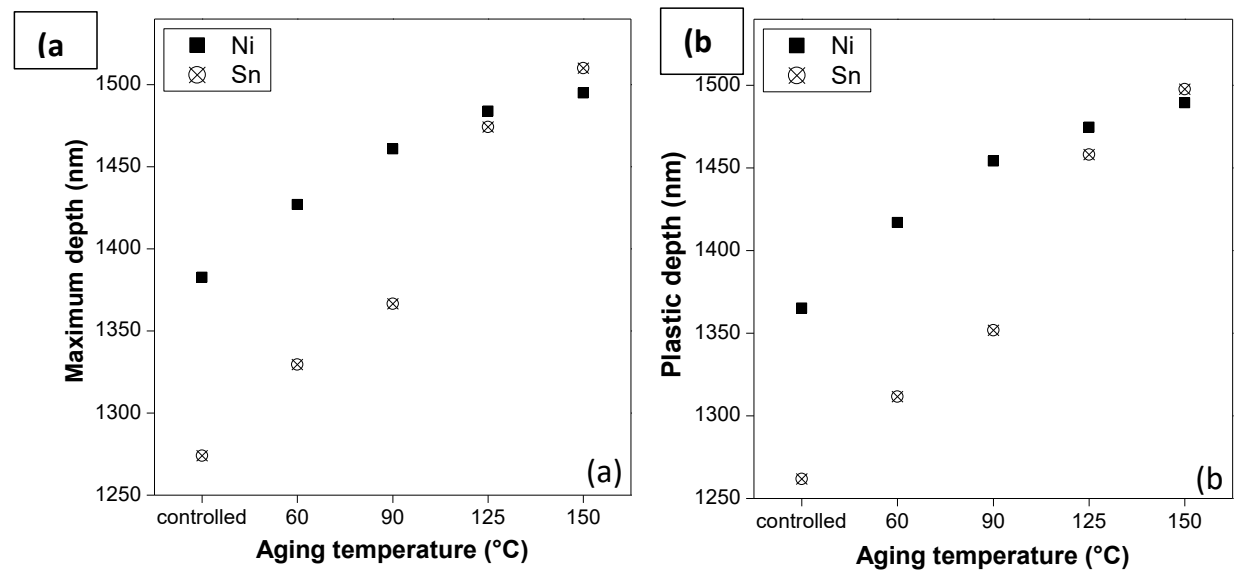

FIGURE 5. (a) Maximum, and (b) plastic depth properties of $\mathrm{Sn}-0.3 \mathrm{Ag}-0.7 \mathrm{Cu}$ solder joint on PCB with different coating subjected to aging for $1000 \mathrm{~h}$

Figure 6 shows that the hardness and reduced modulus of the solder joint after exposed to different aging for $1000 \mathrm{~h}$. The hardness of the solder joint on $\mathrm{PCB} / \mathrm{Cu}$ with Sn coating is $246 \mathrm{MPa}$ for a controlled sample and noticeably reduced to $177 \mathrm{MPa}$ after exposed to aging at $150{ }^{\circ} \mathrm{C}$. While fewer changes on the hardness for solder 
joint on $\mathrm{PCB} / \mathrm{Cu}$ with $\mathrm{Ni}$ coating, $211 \mathrm{MPa}$ to $179 \mathrm{MPa}$ approximately $16 \%$ reduction as compared $28 \%$ for $\mathrm{Sn}$ coating. Reduce modulus result for solder joint on $\mathrm{PCB} /$ $\mathrm{Cu}$ with $\mathrm{Sn}$ coating from 133 decreased to $54 \mathrm{GPa}$ after aging at $150{ }^{\circ} \mathrm{C}$. Similar observation but fewer changes are observed for solder joint on $\mathrm{PCB} / \mathrm{Cu}$ with $\mathrm{Ni}$ coating from 151 to $88 \mathrm{GPa}$, approximately $42 \%$ as compared to Sn coating, 59\% reduction from controlled sample. The findings show that the hardness and reduced modulus are decreased with the increase of the aging temperature.
These observations suggest there are softening effects on the solder joint strength after the aging test. This finding agrees with plastic work which increased from 5.73 to $8.48 \mathrm{~nJ}$ for Sn coating and 6.32 to $7.31 \mathrm{~nJ}$ for Ni coating after aging at $150{ }^{\circ} \mathrm{C}$ (Figure 7). Meanwhile, the elastic work has decreased from 0.19 to $0.11 \mathrm{~nJ}$ for $\mathrm{Sn}$ coating and 0.13 to $0.08 \mathrm{~nJ}$ for $\mathrm{Ni}$ coating after aging at $150{ }^{\circ} \mathrm{C}$ (Figure 7). The decrease of elastic properties of $\mathrm{Sn}$ and Ni coating by 42 and $38 \%$, whereas the increase of plastic work by 48 and $16 \%$ of $\mathrm{Sn}$ and Ni coating.
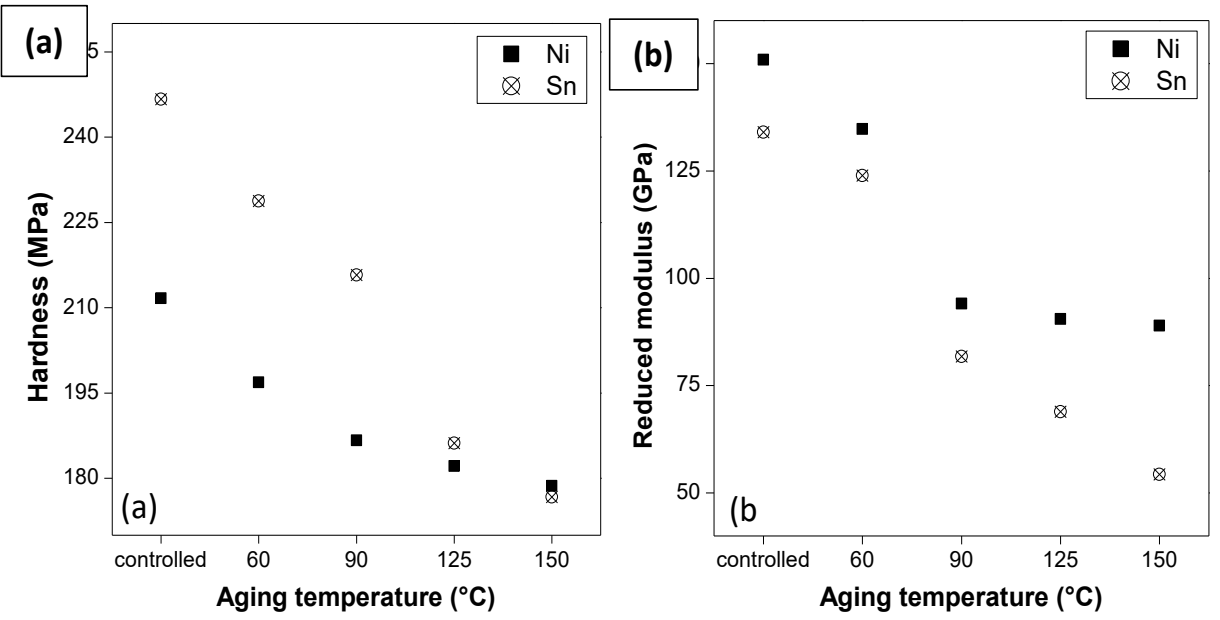

FIGURE 6. (a) Hardness, and (b) reduced modulus properties of Sn-0.3Ag$0.7 \mathrm{Cu}$ solder joint on PCB with different coating subjected to aging for $1000 \mathrm{~h}$
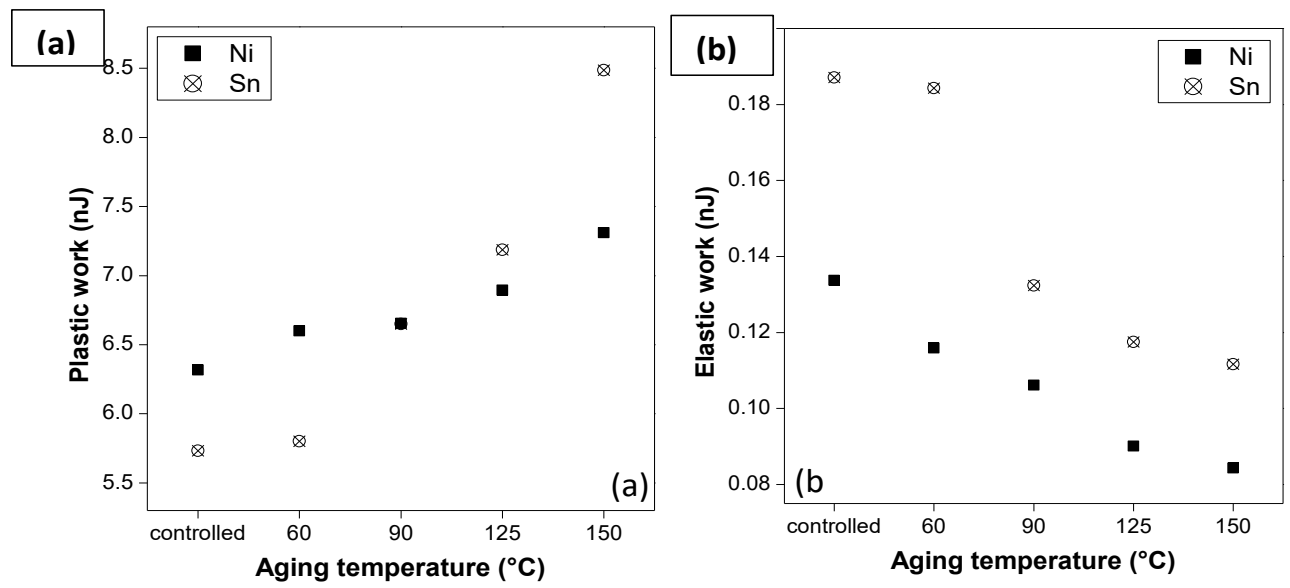

FIGURE 7. (a) Plastic, and (b) elastic work properties of Sn-0.3Ag-0.7Cu solder joint on PCB with different coating subjected to aging for $1000 \mathrm{~h}$ 


\section{CONCLUSION}

The nanoindentation approach has successfully discovered the joining stability of $\mathrm{Sn}-0.3 \mathrm{Ag}-0.7 \mathrm{Cu}$ solder joint on $\mathrm{PCB} / \mathrm{Cu}$ with different coating subjected to aging for $1000 \mathrm{~h}$. It was found that the solder joint on Ni coated $\mathrm{PCB} / \mathrm{Cu}$ is more stable as compared to Sn coating after subjected to aging at $1000 \mathrm{~h}$. Solder joint on Ni coated $\mathrm{PCB} / \mathrm{Cu}$ shown smaller microstructural changes in terms of intermetallic compound layer thickness by $3.7 \mu \mathrm{m}$ due to aging temperature for $1000 \mathrm{~h}$. Smaller micromechanical changes of $\mathrm{Ni}$ coated $\mathrm{PCB} / \mathrm{Cu}$ by $16 \%$ for hardness, $42 \%$ reduce modulus, $38 \%$ elastic and $16 \%$ plastic work as compared to Sn coating.

\section{ACKNOWLEDGEMENTS}

This work is supported by the Ministry of Education, Malaysia under Fundamental Research Grant Scheme (FRGS/1/2019/STG07/UKM/03/1), Universiti Kebangsaan Malaysia (UKM) under Geran Galakan Penyelidik Muda (GGPM-2019-056) and Redring Solder (M) Sdn. Bhd. for research materials and collaboration work.

\section{REFERENCES}

Abu Bakar, M., Jalar, A., Abdullah, M.Z., Ibrahim, N.S. \& Ambak, M.A. 2018. Controlling of Intermetallic compound solder interconnection-printed circuit board using nickel coating. Sains Malaysiana 47(9): 2157-2162.

Ahmed, S., Hasnine, M., Suhling, J.C. \& Lall, P. 2017. Mechanical characterization of SAC solder joints at high temperature using nanoindentation. Proceedings of the 67th Electronic Components and Technology Conference (ECTC). pp. 1128-1135.

Anuar, R.A.M. \& Osman, S.A. 2020. The formation of intermetallic layer structure of SAC405/Cu and SAC405/ ENImAg solder joint interfaces. Soldering \& Surface Mount Technology. doi/10.1108/SSMT-03-2019-0009.

Bakar, M.A., Jalar, A. \& Ismail, R. 2018. Reassessment of stereometric quantitative measurements on the growth of intermetallic compound for solder connections. Sains Malaysiana 47(4): 805-810.

Che Ani, F., Jalar, A., Saad, A.A., Khor, C.Y., Ismail, R., Bachok, Z., Abas, M.A. \& Othman, N.K. 2018. SAC-xTiO2 nano-reinforced lead-free solder joint characterizations in ultra-fine package assembly. Soldering \& Surface Mount Technology 30(1): 1-13.

Fahim, A., Ahmed, S., Suhling, J.C. \& Lall, P. 2018. Nanoindentation measurements of the mechanical properties of individual phases within lead free solder joints subjected to isothermal aging. International Electronic Packaging Technical Conference and Exhibition 51920: V001T03A005.

Genanu, M., Wilcox, J., Cotts, E., Choi, J.J. \& Kim, K.S. 2017. Effect of process thermal history on the microstructure of copper pillar SnAg solder joints. Proceedings of SMTA International.
Guo, B., Kunwar, A., Zhao, N., Chen, J., Wang, Y. \& Ma, H. 2018. Effect of $\mathrm{Ag}_{3} \mathrm{Sn}$ nanoparticles and temperature on $\mathrm{Cu}_{6} \mathrm{Sn}_{5} \mathrm{IMC}$ growth in $\mathrm{Sn}-\mathrm{Ag} / \mathrm{Cu}$ solder joints. Materials Research Bulletin 99: 239-248.

Hasnine, M., Suhling, J.C. \& Bozack, M.J. 2017. Effects of high temperature aging on the microstructural evolution and mechanical behavior of SAC305 solder joints using synchrotron X-ray microdiffraction and nanoindentation. Journal of Materials Science: Materials in Electronics 28(18): 13496-13506.

Huber, Z., Wojewoda-Budka, J., Wierzbicka-Miernik, A., Sypien, A., Szczerba, M. \& Zieba, P. 2016. Influence of phosphorous content on microstructure development at the Ni-P plating/SAC interface. Electronic Materials Letters 12(1): 178-185.

Ismail, N., Jalar, A., Abu Bakar, M., Safee, N.S., Wan Yusoff, W.Y. \& Ismail, A. 2020. Microstructural evolution and micromechanical properties of SAC305/CNT/CU solder joint under blast wave condition. Soldering and Surface Mount Technology. doi/10.1108/SSMT-11-2019-0035.

Jalar, A., Bakar, M.A. \& Ismail, R. 2020. Temperature dependence of elastic-plastic properties of fine-pitch SAC 0307 solder joint using nanoindentation approach. Metallurgical and Materials Transactions A: Physical Metallurgy and Materials Science 51(3): 1221-1228.

JEDEC Standard JESD22-A103C. 2009. High Temperature Storage Life. JEDEC Solid State Technology Association.

Khodabakhshi, F., Sayyadi, R. \& Javid, N.S. 2017. Lead free Sn$\mathrm{Ag}-\mathrm{Cu}$ solders reinforced by $\mathrm{Ni}$-coated graphene nanosheets prepared by mechanical alloying: Microstructural evolution and mechanical durability. Materials Science and Engineering: A 702: 371-385.

Kim, M.S. \& Nishikawa, H. 2017. Transmission electron microscopy investigation on the oxidation behavior of electroless $\mathrm{Ni} / \mathrm{immersion} \mathrm{Au}$ surface finish at $250^{\circ} \mathrm{C}$. Journal of Nanoscience and Nanotechnology 17(11): 85228527.

Kunwar, A., Ma, H., Ma, H., Sun, J., Zhao, N. \& Huang, M. 2016. On the increase of intermetallic compound's thickness at the cold side in liquid $\mathrm{Sn}$ and $\mathrm{SnAg}$ solders under thermal gradient. Materials Letters 172: 211-215.

Nor Ilyana, M.N. 2017. Evaluation of corrosive environment impact on low cost Fe/Al ADDED SAC105 solder alloys/ Nor Ilyana Muhd Nordin. University of Malaya, Ph.D. Thesis (Unpublished).

Plevachuk, Y., Tkach, O., Švec, P., Yakymovych, A. \& Orovcik, L. 2019. Nanocomposite solders: An influence of un-coated and $\mathrm{Au}$-coated carbon nanotubes on morphology of $\mathrm{Cu} /$ Sn-3.0 Ag-0.5 Cu/Cu solder joints. 2019 IEEE 2nd Ukraine Conference on Electrical and Computer Engineering (UKRCON). pp. 722-725.

Ramli, M.I.I., Salleh, M.M., Sobri, F.M., Narayanan, P., Sweatman, K. \& Nogita, K., 2019. Relationship between free solder thickness to the solderability of $\mathrm{Sn}-0.7 \mathrm{Cu}-0.05$ $\mathrm{Ni}$ solder coating during soldering. Journal of Materials Science: Materials in Electronics 30(4): 3669-3677.

Shang, S., Wang, Y., Wang, Y., Ma, H. \& Kunwar, A. 2019. Enhancement of hardness of bulk solder by doping $\mathrm{Cu}$ 
nanoparticles at the interface of $\mathrm{Sn} / \mathrm{Cu}$ solder joint. Microelectronic Engineering 208: 47-53.

Tang, Y., Luo, S.M., Wang, K.Q. \& Li, G.Y. 2016. Effect of nano$\mathrm{TiO}_{2}$ particles on growth of interfacial $\mathrm{Cu}_{6} \mathrm{Sn}_{5}$ and $\mathrm{Cu}_{3} \mathrm{Sn}$ layers in $\mathrm{Sn}-3.0 \mathrm{Ag}-0.5 \mathrm{Cu}-\mathrm{TiO}_{2}$ solder joints. Journal of Alloys and Compounds 684: 299-309.

Wang, F., Li, D., Zhang, Z., Wu, M. \& Yan, C. 2017. Improvement on interfacial structure and properties of $\mathrm{Sn}-58 \mathrm{Bi} / \mathrm{Cu}$ joint using $\mathrm{Sn}-3.0 \mathrm{Ag}-0.5 \mathrm{Cu}$ solder as barrier. Journal of Materials Science: Materials in Electronics 28(24): 1905119060.

Xiong, M.Y. \& Zhang, L. 2019. Interface reaction and intermetallic compound growth behavior of $\mathrm{Sn}-\mathrm{Ag}-\mathrm{Cu}$ lead-free solder joints on different substrates in electronic packaging. Journal of Materials Science 54: 1741-1768.

Xu, D., Wang, Y., Xiong, B. \& Li, T. 2017. MEMS-based thermoelectric infrared sensors: A review. Frontiers of Mechanical Engineering 12(4): 557-566.

Xu, R., Liu, Y. \& Sun, F. 2019. Effect of isothermal aging on the microstructure, shear behavior and hardness of the $\mathrm{Sn} 58 \mathrm{Bi} / \mathrm{Sn} 3.0 \mathrm{Ag} 0.5 \mathrm{Cu} / \mathrm{Cu}$ solder joints. Results in Physics 15: 102701
Yakymovych, A., Plevachuk, Y., Švec, P., Janičkovič, D., Šebo, P., Beronska, N., Nosko, M., Orovcik, L., Roshanghias, A. \& Ipser, H. 2017. Nanocomposite SAC solders: Morphology, electrical and mechanical properties of $\mathrm{Sn}-3.8 \mathrm{Ag}-0.7 \mathrm{Cu}$ solders by adding Co nanoparticles. Journal of Materials Science: Materials in Electronics 28(15): 10965-10973.

Yao, P. \& Li, X. 2020. Investigation on shear fracture of different strain rates for $\mathrm{Cu} / \mathrm{Cu} 3 \mathrm{Sn} / \mathrm{Cu}$ solder joints derived from $\mathrm{Cu}-15 \mu \mathrm{m} \mathrm{Sn}-\mathrm{Cu}$ sandwich structure. Journal of Materials Science: Materials in Electronics 31(4): 28622876.

Institute of Microengineering and Nanoelectronics (IMEN) Universiti Kebangsaan Malaysia 43600 UKM Bangi, Selangor Darul Ehsan Malaysia

*Corresponding author; email: maria@ukm.edu.my

Received: 12 August 2020

Accepted: 18 August 2020 